\title{
METAL ACCUMULATION IN 5 NATIVE PLANTS GROWING ON ABANDONED CU-TAILINGS PONDS
}

\author{
MANAB DAS ${ }^{1}{ }_{-}$-SUBODH KUMAR MAITI ${ }^{1}$ \\ ${ }^{1}$ Centre of Mining Environment \\ Indian School of Mines, Dhanbad, Jharkhand, INDIA. \\ (+91 0326-22063720) \\ e-mail:manab_ism@rediffmail.com \\ (Received $27^{\text {th }}$ Febr 2007 ; accepted $13^{\text {th }}$ May 2007)
}

\begin{abstract}
Tailings and plants were sampled from the abandoned Cu-tailing ponds of Rakha mines, Jharkhand, India. Tailings have high concentration of $\mathrm{Cu}, \mathrm{Ni}$ and characterized by moderately acid environment and low nutrient contents. Plants belonging to 5 genera and 4 families were collected and analysed for metals in their above and underground tissues. Plant communities respond differently depending on their ability to uptake or exclude a variety of metals. Accumulated metals were mostly retained in root tissue indicating that an exclusion mechanism for metal tolerance widely exists in them. Retention of some metals more than toxic level in the above ground tissues of some plants suggests the presence of internal metal detoxification and tolerance mechanisms in them.
\end{abstract}

Keywords: Cu-tailings, heavy metal, metal tolerance, natural vegetation.

\section{Introduction}

Mill tailings are generally characterised by high metal content, low fertility and obviously low water holding capacity. A vegetative cover on such tailings may play an important role in metal removal via filtration, adsorption and cation exchange, and through plant induced chemical changes in the rhizosphere. Additionally, it helps to avoid dispersion of contaminants through wind erosion and by reducing water percolating through the soil. This may keep contaminants away from underlying ground water by stabilising them in the soil profile [27]. Some plants phytostabilise heavy metals in the rhizosphere through root exudates immobilisation [4] whilst other species incorporate them into root tissues [16]. Some plant species also transfer metals to their aboveground tissues, potentially allowing the soil to be decontaminated by harvesting the aboveground parts of the plants. The success of any phytoremediation technique depends upon the identification of suitable species that hyperaccumulate trace elements and produce large amount of biomass using established crop production and management practices $[3,8,9]$. Thus collecting plant species on contaminated sites prior to evaluation of plant metal concentration can be used to get information about specific plant behavior in this environment, which may be effective for selecting potential plants to be used in mine remediation and also to complete data about metal dispersion, with reference to their mobility to biomass $[12,14]$. There are many evidences that plants grown on metal enriched soil can accumulate high amount of heavy metals in their tissues such as Silene armeria [12], Typha latifolia [29], Festuca sp. [2], Salix viminalis [20], Vetiveria zizanioides [28], Juncus conglomerates [14]. In Rakha mines area, Jharkhand there are several abandoned Cu-tailings ponds that caused severe metal pollution to the nearby areas. Our investigation in $\mathrm{Cu}$-tailings ponds revealed that many plant species could thrive in heavily metal enriched tailings. Henceforth, the concentration of $\mathrm{Cu}, \mathrm{Ni}, \mathrm{Mn}, \mathrm{Zn}, \mathrm{Pb}$ and $\mathrm{Cd}$ were examined in both the above and 
underground tissues of 5 naturally growing plant species. The main objectives of our study were:

- to evaluate the different form of toxic metals present in $\mathrm{Cu}$ tailings and their bioavailability;

- to identify plant species grown naturally on abandoned $\mathrm{Cu}$-tailings and to determine the ability of these species to accumulate and tolerate $\mathrm{Cu}, \mathrm{Ni}, \mathrm{Mn}$ and $\mathrm{Zn}$ in their tissue.

- to examine the extent of metal translocation from underground tissue to aboveground tissue in different plants for different metals.

The above information could be used for selection of appropriate plant species in metal enriched $\mathrm{Cu}$-tailing ponds to exploit removal potential of heavy metals by naturally growing vegetation combined with other chemical and biological process.

\section{Materials and methods}

\section{Sampling location and plant species}

The Rakha $\mathrm{Cu}$ mines located at about $50 \mathrm{~km}$ away from Tatanagar by road and at a distance of $7 \mathrm{~km}$ from Rakha mines railway station, East Singhbhum, Jharkhand. According to Dunn and Dey [13] and Deb and Sarkar [10] the mineral distribution of Rakha ore follow the order as silicious gangue $(85.12 \%)>$ chalcopyrite $(8.48 \%)>$ magnetite $(3.82 \%)>$ pyrite and marcasite $(2.37 \%)>$ covellite, vellerite and cubanite $(0.12 \%)>$ molybdenite $(0.06 \%)>$ violarite, linnacite and tellurites $(0.03 \%)$. The climate is humid tropical, temperature variation lies between $39^{\circ} \mathrm{C}(\max )$ and $11^{\circ} \mathrm{C}(\min )$. Rainy season experiences during June, July, August and September and average rainfall is $1800 \mathrm{~mm}$ per annum. The tailing ponds studied had been abandoned from 2001, remained mostly dry, barren and growth of some metal and draught tolerant species had been observed. Five plants were collected from the selected site during winter season (December 2004) which belonged to five genera and four families (Table 1).

\section{Plant sampling and analysis}

Plant samples were collected in at least three replicates and each replicate consisted of subsamples. The herbaria were prepared for all the species and identified at Botanical Survey of India (BSI, Howrah). Individual plants were divided into two components root and shoot, carefully washed in deionized water and attention was given to washing, until visual inspection revealed that no solid particles remained adhering to the roots or shoots. Plant samples were then oven dried at $80^{\circ} \mathrm{C}$ overnight and ground into powder for metal concentration analysis. Metal analysis of the plant samples was carried out by acid digestion (5: 1 conc. $\mathrm{HNO}_{3}$ and conc. $\mathrm{HClO}_{4}, \mathrm{v} / \mathrm{v}$ ) of accurately $0.5 \mathrm{~g}$ of plant tissue [28] followed by measurement of metal concentration using Atomic Absorption Spectrometry (AAS).

\section{Tailing sampling and analysis}

The tailings loosely adhered to roots were gently shaken off and the rhizosphere tailings adhering to roots were separated by hand. Rhizosphere soils were then air-dried and sieved through 500-micron nylon mesh. Samples were then analysed for total metals, DTPA and $\mathrm{CaCl}_{2}$ extractable fractions, $\mathrm{pH}$, electrical conductivity (EC), organic carbon (OC), available $\mathrm{N}$, exchangeable cations $(\mathrm{Ca}, \mathrm{Mg}, \mathrm{Na}$ and $\mathrm{K}$ ) and cation exchange capacity (CEC). The $\mathrm{pH}$ was measured using 1:2.5 (w/v) soil/deionised water 
ratio by a $\mathrm{pH}$ meter and the same was also used for conductivity measurement in an EC meter. OC was determined by the Walkley-Black procedure [18], CEC by ammonium acetate method, available $\mathrm{N}$ by the alkaline permanganate method [23]. Exchangeable cations were extracted with $1 \mathrm{~N}$ neutral $\mathrm{NH}_{4} \mathrm{OAc}(\mathrm{pH}$ 7) in 1:5 (w/v) soil: extracting solution ratio prior to analysis of $\mathrm{Ca}$ and $\mathrm{Mg}$ in $\mathrm{AAS}$ and $\mathrm{Na}$ and $\mathrm{K}$ in flame photometer. For total metal content, accurately $0.5 \mathrm{~g}$ oven dried $\left(80{ }^{0} \mathrm{C}\right.$ for overnight $)$ tailings was digested twice with $5 \mathrm{ml}$ of $3: 1: 1 \mathrm{HCl}: \mathrm{HNO}_{3}$ : $\mathrm{HF}$ and once with $5 \mathrm{ml}$ aqua regia in a covered teflon-beaker. Digested mass was then boiled with $1 \% \mathrm{HNO}_{3}$ solution, filtered in a volumetric flask followed by addition of $1 \% \mathrm{HNO}_{3}$ solution to make a final volume of $100 \mathrm{ml}$. For DTPA and $\mathrm{CaCl}_{2}$ extractable fractions oven dried tailings were extracted with $0.005 \underline{M}$ DTPA (20g tailings extracted by $40 \mathrm{ml}$ solution) and $0.01005 \underline{M} \mathrm{CaCl}_{2}(5 \mathrm{~g}$ tailings extracted by $50 \mathrm{ml}$ solution) respectively [17]. Total and extractable metal contents were measured by using Atomic Absorption Spectrometry (AAS) for $\mathrm{Cu}, \mathrm{Ni}$, $\mathrm{Mn}, \mathrm{Zn} \mathrm{Pb}$ and $\mathrm{Cd}$.

\section{Translocation factor}

The translocation factor for metals within a plant was determined as the ratio of $[\text { Metal }]_{\text {Shoot }} /[\text { Metal }]_{\text {Root }}$ to evaluate the extent of metal translocation from roots to shoots $[22,11]$.

\section{Results}

\section{Characteristics of tailings}

The tailings at the abandoned $\mathrm{Cu}$-tailings ponds are slightly acidic with an average $\mathrm{pH}$ of 6.3 and EC $0.32 \mathrm{dSm}^{-1}$ (Table 2). Organic carbon content varied widely $(0.12$ $1.3 \%$ ) with an average value of $0.5 \%$. The available nitrogen in tailings was very low ranging from 41 to $219 \mathrm{ppm}$ with an average of $103 \mathrm{ppm}$. This macronutrient most often limits plant establishment, either because of its low content or because of a lack of the microorganisms which make it bioavailable [6]. Regarding exchangeable cations, $\mathrm{Ca}$ was the most abundant among alkaline-earth cations followed by $\mathrm{Mg}, \mathrm{K}$ and $\mathrm{Na}$. $\mathrm{K}$ contents in almost all the samples were lower than $0.2 \mathrm{cmol}(+) \mathrm{kg}^{-1}$ revealing a deficiency of this element [21]. The average cation exchange capacity observed as 4.39 cmol $(+) \mathrm{kg}^{-1}$. The heavy metal content in tailings was very high and varied widely (Table 3). With regard to total concentration tailings was characterised by high $\mathrm{Cu}$ (1008-1803 $\mathrm{mg} \mathrm{kg}^{-1}$ ) followed by Ni (323-656 mg kg-1), Mn (142-179 mg kg-1), Zn (66$\left.82 \mathrm{mg} \mathrm{kg}^{-1}\right), \mathrm{Pb}\left(26-51 \mathrm{mg} \mathrm{kg}^{-1}\right)$ and $\mathrm{Cd}\left(7-11 \mathrm{mg} \mathrm{kg}^{-1}\right)$. However, in the DTPA and $\mathrm{CaCl}_{2}$ fraction $\mathrm{Cu}, \mathrm{Ni}, \mathrm{Mn}$ and $\mathrm{Zn}$ concentration attained slightly different order. $\mathrm{Pb}$ and $\mathrm{Cd}$ in $\mathrm{CaCl}_{2}$ extracts were below the detection limit.

Table 1: General characteristics of plant species identified at abandoned Rakha $\mathrm{Cu}$ tailings pond.

\begin{tabular}{|c|c|c|l|}
\hline Scientific name & Common name & Family & \multicolumn{1}{c|}{ Characteristics } \\
\hline $\begin{array}{c}\text { Ammania } \\
\text { baccifera Linn }\end{array}$ & $\begin{array}{c}\text { Blistering } \\
\text { ammania }\end{array}$ & Lytheraceae & $\begin{array}{l}\text { Herbaceous plant acrid and vesicant, common } \\
\text { in rice fields and has irritant properties. }\end{array}$ \\
\hline $\begin{array}{c}\text { Fimbristylis } \\
\text { dichotoma ( L) } \\
\text { Vahl }\end{array}$ & Tall-fringe rush & Cyperaceae & $\begin{array}{l}\text { Annual sedge, culms, slender, tufted, 20-50 } \\
\text { cm tall, leaves, well developed, shorter than } \\
\text { the stem, prefers wet conditions. }\end{array}$ \\
\hline $\begin{array}{c}\text { Pycreus flavidus } \\
\text { (Retz) Koyama }\end{array}$ & $\begin{array}{c}\text { Yellow Flat- } \\
\text { sedge }\end{array}$ & Poaceae & $\begin{array}{l}\text { Tufted, small annual, or sometimes caespitose } \\
\text { perennial, 15-50 cm, stem 1-2 mm diam., } \\
\text { grows along riversides and brooklets, rice } \\
\text { fields. }\end{array}$ \\
\hline
\end{tabular}




\begin{tabular}{|c|l|l|l|}
\hline $\begin{array}{c}\text { Typha latifolia } \\
\text { Linn. }\end{array}$ & Cattail & Typhaceae & $\begin{array}{l}\text { Perennial plants mostly 1.5-3 m tall, leaves } \\
\text { erect, green, mostly 3-10 mm wide, the } \\
\text { auricles of the leaf sheath rounded and } \\
\text { surpassing the base of the blade, grow in } \\
\text { marshes, shores, stream banks, ditches and } \\
\text { margins of lakes and ponds, usually in } \\
\text { shallow water, more tolerant of brackish or } \\
\text { saline conditions. }\end{array}$ \\
\hline $\begin{array}{c}\text { Echinochola } \\
\text { colona (L) Link }\end{array}$ & Jungle rice & Poaceae & $\begin{array}{l}\text { Tufted annual 20-90cm tall, flowers in } \\
\text { summer and winter, grows in loams, silts and } \\
\text { clays in low places }\end{array}$ \\
\hline
\end{tabular}

Table 2. General properties of tailings.

\begin{tabular}{lc}
\hline \multicolumn{1}{c}{ Parameters } & Mean \pm sd (min-max) \\
\hline $\mathrm{pH}(1: 2.5)$ & $6.29 \pm 0.6(4.8-7.2)$ \\
$\mathrm{EC}\left(\mathrm{dS} \mathrm{m}^{-1}\right)$ & $0.32 \pm 0.14(0.17-0.68)$ \\
Organic carbon (\%) & $0.5 \pm 0.4(0.12-1.3)$ \\
Available nitrogen (ppm) & $103 \pm 68(41-219)$ \\
Exchangeable cations $\left[\mathrm{cmol}(+) \mathrm{kg}^{-1}\right]$ & \\
$\mathrm{Ca}$ & $2.0 \pm 1.0(0.8-4.1)$ \\
$\mathrm{Mg}$ & $0.8 \pm 0.6(0.14-2.34)$ \\
$\mathrm{Na}$ & $0.09 \pm 0.04(0.02-0.16)$ \\
$\mathrm{K}$ & $0.11 \pm 0.09(0.03-0.3)$ \\
$\mathrm{CEC}\left[\mathrm{cmol}(+) \mathrm{kg}^{-1}\right]$ & $4.39 \pm 2.5(1.75-9.43)$ \\
\hline
\end{tabular}

Table 3: The total, DTPA and $\mathrm{CaCl}_{2}$ metal contents in tailings $\left(m g \mathrm{~kg}^{-1}, \mathrm{dw}\right)$.

\begin{tabular}{cccc}
\hline Total metal & $\begin{array}{c}\text { DTPA }(\mathbf{0 . 0 0 5} \underline{\boldsymbol{M}}) \\
\text { extractable metal }\end{array}$ & $\begin{array}{c}\mathbf{C a C l}_{\mathbf{2}}(\mathbf{0 . 0 1} \boldsymbol{M}) \\
\text { extractable metal }\end{array}$ \\
\hline $\mathrm{Cu}$ & $1008-1803$ & $11-199$ & $0.3-30$ \\
$\mathrm{Ni}$ & $323-656$ & $0.3-25$ & $0.2-24$ \\
$\mathrm{Mn}$ & $142-179$ & $0.5-20$ & $0.02-15$ \\
$\mathrm{Zn}$ & $66-82$ & $0.3-1.3$ & $0.07-3.5$ \\
$\mathrm{~Pb}$ & $26-51$ & $0.7-4.3$ & bdl \\
$\mathrm{Cd}$ & $7-11$ & $0.3-0.6$ & bdl \\
\hline
\end{tabular}

bdl $=$ below detection limit

Table 4: Translocation factor (TF $\left.[\text { Metal }]_{\text {Shoot }} /[\text { Metal }]_{\text {Root }}\right)$ in plant species grown on Cutailings pond of Rakha mines.

\begin{tabular}{ccccc}
\hline \multirow{2}{*}{ Plant species } & \multicolumn{4}{c}{ TF } \\
\cline { 2 - 5 } & $\mathrm{Cu}$ & $\mathrm{Ni}$ & $\mathrm{Mn}$ & $\mathrm{Zn}$ \\
\hline Ammania baccifera & 0.06 & 0.37 & 1.70 & 0.20 \\
Fimbristylis dichotoma & 0.20 & 0.36 & 1.45 & 1.0 \\
Pycreus flavidus & 0.09 & 0.09 & 2.71 & 2.46 \\
Typha latifolia & 0.02 & 0.04 & 2.71 & 0.16 \\
Echinocola cholona & 0.12 & 0.46 & 1.30 & 0.96 \\
\hline
\end{tabular}

\section{Metal accumulation and translocation by plants}

Metal accumulation in plant tissue collected from the tailing pond is shown in Figure 1. The data show that metal contents in the plant tissues varied widely among species, indicating their different capacities for metal uptake. T. latifolia accumulated significantly higher $\mathrm{Ni}\left(129 \mathrm{mg} \mathrm{kg}^{-1}\right)$ and $\mathrm{Zn}\left(125 \mathrm{mg} \mathrm{kg}^{-1}\right)$ in its root and higher $\mathrm{Mn}$ in 
both above- and underground tissues than the other species. A. baccifera attained an average concentration of $1613 \mathrm{mg} \mathrm{kg}^{-1} \mathrm{Cu}$ in the underground tissues, which was much higher than that of the other four species, while $F$. dichotoma accumulated significantly higher $\mathrm{Cu}$ and $\mathrm{Ni}$ in its above ground tissues than the other species. On the other hand $P$. flavidus and E. colona accumulated higher $\mathrm{Zn}$ in their aboveground tissues than others.

The translocation factor (TF), the ratio of shoot to root metals indicates internal metal transportation. Present study indicate that $\mathrm{Cu}, \mathrm{Ni}, \mathrm{Zn}$ accumulated by the plants growing on $\mathrm{Cu}$-tailings, were largely retained in roots as shown by general $\mathrm{TF}$ values $<$ 1 (Table 4). Exceptions occurred in F. dichotoma (1.0) and P. flavidus (2.46) for Zn. However, in all the plants TF for Mn was greater than 1 and varied with in the range of 1.3 to 2.7. Among $\mathrm{Cu}, \mathrm{Ni}$ and $\mathrm{Zn}, \mathrm{TF}$ for $\mathrm{Cu}$ was the lowest while $\mathrm{Zn}$ was highest in the species studied whereas in A. baccifera TF value for $\mathrm{Ni}$ was found higher than $\mathrm{Zn}$. The TF values also varied among the plant species. For instance, TF values for $\mathrm{Zn}$ in $A$. baccifera and $F$. dichotoma were 0.2 and 1.0 respectively, although both are collected from the same tailings pond.

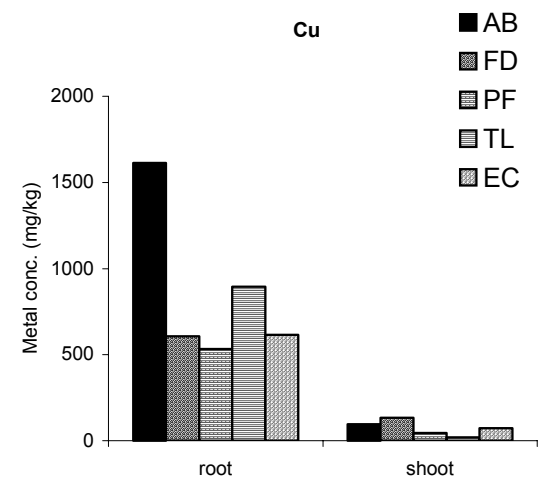

$\mathrm{Mn}$

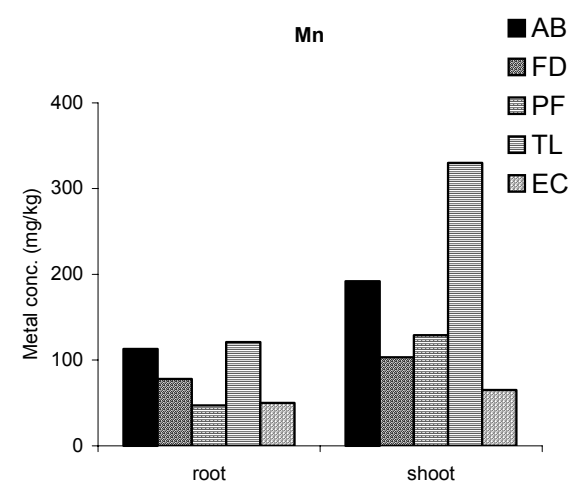

$\mathrm{Ni}$

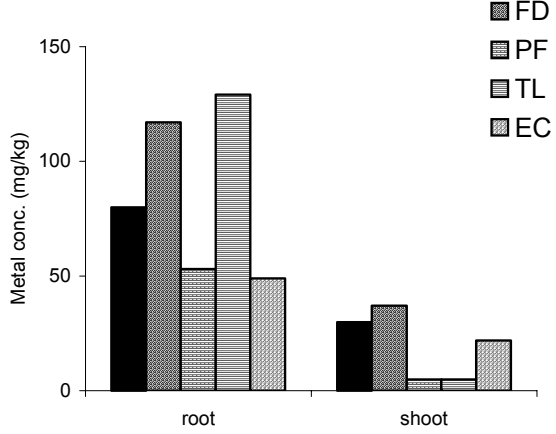

$\mathrm{Zn}$

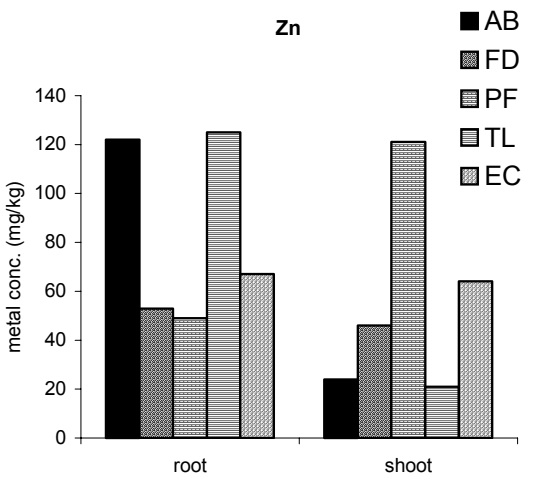

Figure 1: Metal concentrations in roots and shoots of plants collected from abandoned $\mathrm{Cu}$ tailing pond of Rakha mines area. AB: Ammania baccifera; FD: Fimbristylis dichotoma; PF: Prcreus flavidus; TL: Typha latifolia; EC: Echinochola colona. 


\section{Discussion}

The present study reveals that plants like $A$. baccifera, $F$. dichotoma, $P$. flavidus, $T$. latifolia and $E$. colona can colonize sites with low organic carbon and macronutrients but a wide range of metal concentrations (Table 3). According to Tietjen [26] and Kabata-Pendias and Pendias [15] $100 \mathrm{mg} \mathrm{kg}^{-1} \mathrm{Cu}, 100 \mathrm{mg} \mathrm{kg}^{-1} \mathrm{Ni}$ based on total fraction in soil, would be considered toxic to plants. Concentration of $\mathrm{Cu}, \mathrm{Ni}$ in the tailings greatly exceeds these values; therefore the five plants grown in the study area have exhibited high metal tolerance.

The general trend (Figure 1) shows that the root tissue accumulate significantly greater concentration of metals than shoots indicating high plant availability of the substrate metals as well as its limited mobility once inside the plant. Except $\mathrm{Mn}$, concentration of other metals in aboveground tissues were maintained at low levels and varied in a short range compared to underground tissues (Figure 1). Such, exclusions of metals from above ground tissues has been suggested as a metal tolerant strategy adopted by different plants $[24,25]$. Therefore, the elevated metal concentrations in the root tissue and low translocation to the aboveground tissue in the five plants examined might suggest that they are capable of rather well balanced uptake and translocation of metals under heavily metal-enriched substrate. $\mathrm{Cu}$ is an essential element to plant growth but will cause toxic effects when shoots or leaves accumulate more than $20 \mathrm{mg}$ $\mathrm{kg}^{-1}$ [5]. In almost all the plant species examined, $\mathrm{Cu}$ concentration in aboveground tissues were found significantly higher than the above-mentioned value. Compared to shoots, $\mathrm{Cu}$ concentration in the under ground tissues were maintained at higher level and varied widel in the range of $532-1613 \mathrm{mg} \mathrm{kg}^{-1}$. The concentration of $\mathrm{Ni}$ in plants generally reflects the concentration of the element in the soil and the mobility of $\mathrm{Ni}$ in soil increases as the $\mathrm{pH}$ and $\mathrm{CEC}$ decreases [1]. Except $F$. dichotoma and T. latifolia, Ni concentration in above- and underground tissue were below or within the toxicity range of $10-100 \mathrm{mg} \mathrm{kg}^{-1}$ [15]. The average $\mathrm{Ni}$ concentration in the underground tissue of the above two plants was 117 and $129 \mathrm{mg} \mathrm{kg}^{-1}$ respectively. However, $\mathrm{Ni}$ in the aboveground tissue of $T$. latifolia was found less than the toxic level indicating restricted translocation of $\mathrm{Ni}$ from root to shoot. Existence of such a mechanism is the result of evolution rather than an innate physiological tolerance [7]. Uptake of Mn by plants is a function of the concentration of this element present in ionic form in the soil solution and the concentration present on the exchange sites of the cation exchange complex, i.e. the available or labile pool. The highest concentration of $\mathrm{Mn}$ was found in the aboveground tissue of T. latifolia whereas lowest value corresponded to E. colona. Although in T. latifolia, $\mathrm{Mn}$ accumulation was within the range considered as toxic by Kabata-Pendias and Pendias [15], in the other species the Mn concentrations were in the range of (20-300 $\left.\mathrm{m} \mathrm{kg} \mathrm{k}^{-1}\right)$ considered as normal by these authors. In comparison with the tailings and the underground tissues, the concentration of $\mathrm{Mn}$ in shoots were maintained at higher level and varied within range $49-341 \mathrm{mg} \mathrm{kg}^{-1}$ in the plants investigated. It is to be pointed out that the limits of Mn toxicity were also never reached in the total Mn concentration in tailings. $\mathrm{Zn}$ is an essential element to all plants. Plants predominantly absorb $\mathrm{Zn}$ as a divalent cation which act either as a metal component of enzymes or as a functional, structural or regulatory co-factor of a large number of enzymes [1]. The concentrations of $\mathrm{Zn}$ in the examined plants were within the normal values (20-400 $\mathrm{mg}$ $\mathrm{kg}^{-1}$ ) reported by Reeves and Baker [19]. The highest concentration of Zn (121 mg kg $\left.{ }^{-1}\right)$ in the aboveground tissue was found in P. flavidus. Plants like A. baccifera and $T$. latifolia were found to accumulate more $\mathrm{Zn}$ in their underground tissue than compare to shoot whereas in $F$. dichotoma and $E$. colona, $\mathrm{Zn}$ attained nearly equal distribution. 
Present investigation reveals that all the plant species studied could tolerate excess $\mathrm{Cu}$ both in their root as well as shoot. A. baccifera, $F$. dichotoma and T. latifolia were the species accumulating Ni higher than toxic levels $\left(100 \mathrm{mg} \mathrm{kg}^{-1}\right)$ in their underground tissues. The higher than toxic levels of metal concentration in some species indicate that internal metal detoxification tolerance mechanisms might exists in these naturally colonising plants, in addition to their exclusion strategies [24,25].

\section{Conclusions}

The present study shows that tailings in abandoned $\mathrm{Cu}$-tailings ponds are slightly acidic, contain low $\mathrm{N}, \mathrm{Ca}, \mathrm{Mg}, \mathrm{K}$ and are heavily enriched with toxic metals. Concentration of $\mathrm{Cu}, \mathrm{Ni}$ and $\mathrm{Cd}$ in total fraction in most cases exceeded the toxicity threshold limits. The most abandoned metal in total fraction of tailings was $\mathrm{Cu}$ followed by $\mathrm{Ni}$ with comparatively lower amount of $\mathrm{Mn}, \mathrm{Zn}, \mathrm{Pb}$ and $\mathrm{Cd}$. Despite the chemical limitation many plants can colonize this heavy metal enriched tailings pond and are found to accumulate a wide range of toxic metals. Low metal translocation into shoots indicates that metal tolerance in natural vegetation grown on tailings may mainly depend on the metal exclusion ability of underground tissue. Metal accumulation higher than toxic level in some plants indicates that they might have developed some internal detoxification metal tolerance mechanisms. These species therefore, may be considered as tolerant to some elements and hence can be used for detoxification of metal enriched Cu-tailings.

Acknowledgements: The authors wish to thank Dr. P. V. Prasanna, Deputy Director and Mr. A. Bhattacharya, Curator, Central National Herbarium, Botanical Survey of India for help in identification of plant species and to the Hindustan Copper Limited, Ghatsila, for providing assistance in carrying out the field work.

\section{REFERENCES}

[1] Alloway, B.J. (1990): Heavy metals in soil. Blackie Acadamic and Professional, London.

[2] Alvarez, E., Fernandez, M., Vaamonde, C., Fernandez-Sanjurizo, M.J. (2003): Heavy metals in the dump of an abandoned mine in Galicia ( $\mathrm{N}$ W Spain) and in the spontaneously occuring vegetation. The Science of the Total Environment. 313; 185-197.

[3] [Baker, A.J.M., Reeves, R.D. and McGrath, S.P. (1991): In situ decontamination of heavy metal polluted soils using crops of metal-accumulating plants- a feasibility study. In situ bioreclamation (ed. Hinchee, R.E. and Olfenbuttel, R.F.). Butterworth-Heinemann, Boston; pp,.600-605.

[4] Blaylock, M.J. and Huang, J.W. (2000): Phytoextraction of metals. In Phytoremediation of toxic metals: Using plants to clean up the environment. (ed. Rakshin, I. and Ensley, B.D.). John Wiley and Sons Inc., New York; pp,314.

[5] Borkert ,C.M., Cox, F.R. and Tucker, M.R. (1998): Zinc and Copper toxicity in peanut, soyabean, rice and corn in soil mixtures. Communications in Soil Science and plant Analysis. 29; 2991-3005.

[6] Bower, J.F., Bond, J.J., Sandoval, F.M. and Willis, W.O. (1974): Nitrification in Paleocene shale. Science. 183;1077.

[7] Breadshaw, A.D. (1993): Understanding the fundamentals of succession. In Primary succession on land. Eds. Miles J and Walton D H. Blackwell, Oxford. 
[8] Brooks, R.R. (1983): Biological methods of prospecting for minerals. WileyInterscience, New York; pp, 313.

[9] Brooks, R.R. (1998): Plants that hyperaccumulate trace metals. CAB International, Wallingford, UK; pp, 380.

[10] Deb, M. and Sarkar, S.C. (1975): Sulphide ore bodies and their relation to structure at Roam-Rakha mines-Tamapahar sections, Singhbhum copper belt, Bihar. Recent Researches in Geology 2; 247-264.

[11] Deng, H., Ye, Z.H. and Wong, M.H. (2004): Accumulation of lead, zinc, copper and cadmium by 12 wetland species thriving in metal-contaminated sites in China. Environmental Pollution. 132; 29-40.

[12] Dinelli, E. and Lombini, L. (1996): Metal distribution in plants growing on copper mine spoils in Northern Apennies, Italy: the evaluation of seasonal variations. Applied Geochemistry. 11; 375-385.

[13] Dunn, J.A. and Dey, A.K. (1942): Geology and Petrology of Eastern Singhbhum and surrounding areas. Mem. Geol. Surv. India; 69(2).

[14] Freitas, H., Prasad, M.N.V. and Pratas, J. (2004): Plant community tolerant to trace elements growing on the degraded soils of Sao Domingos mine in the south east of Portugal: enviromental implications. Enviroment International. 30; 65-72.

[15] Kabata-Pendias, A. and Pendias, K. (1992): Trace elements in Soils and Plants, 2nd Ed., CRC press, Ann Arbor.

[16] Khan, A.G. (2001) Relationship between chromium biomagnification ratio, accumulation factor, and mycorrhizae in plants growing on tannery effluentpolluted soil. Environ. Int. 26; 417-423.

[17] Lopez-Sanchez, J.F., Sahuquilo, A., Rauret, G., Lachica, M., Barahona, E., Gomez, A., Ure, A.M., Muntau, H. and Quevauviller, P.H. (2002): Extraction procedures for soil analysis. In Methodologies in soil and sediment fraction studies: single and sequential extraction procedures. (ed. Quevauviller, P.H.), Royal Society of Chemistry, Cambridge, UK; pp, 28-65.

[18] Nelson, D.W. and Sommers, L.E. (1982): Total carbon, organic carbon and organic matter. In Methods of soil analysis, Part 2. Chemical and Microbiological Properties, second ed. (ed. Page, A.L.), American Society of Agronomy, Madison, WI; pp, 539-579.

[19] Reeves, R.D. and Baker, A.J.M. (2000): Metal accumulating plants. In Phytoremediation of toxic metals: Using plant to clean up the environment. (eds. Raskin, I. and Ensley, B.D.),.Wiley, New York; pp,193-230.

[20] Rosseli, W., Keller, C. and Boschi, K. (2003): Phytoextraction capacity of trees growing on a metal contaminated soil. Plant and Soil. 256; 265-272.

[21] Sanchez, P.A., Couto, W. and Boul, S.W. (1982): The fertility capability soil classification system: interpretation, applicability and modification. Geoderma, 283-309.

[22] Stoltz, E .and Greger, M. (2002): Accumulation properties of $\mathrm{As}, \mathrm{Cd}, \mathrm{Cu}, \mathrm{Pb}$ and $\mathrm{Zn}$ by four wetland plant species growing on submerged mine tailings. Environmental and Experimental Botany. 47; 271-280.

[23] Subbiah, B. V. and Asija, G.L. (1956): A rapid procedure for the determination of available nitrogen in soils. Curr Sci. 25; 259-260.

[24] Taylor, G.J. and Crowder, A. A. (1983a): Uptake and accumulation of heavy metals by Typha latifolia in wetlands of the Sudbury, Ontario region. Canadian Journal of Botany. 61; 63-73. 
[25] Taylor, G .J. and Crowder, A. A. (1983b): Uptake and accumulation of copper, nickel, and iron by Typha latifolia grown in solution culture. Canadian Journal of Botany. 61; 1825-1830.

[26] Tietjen, C. (1975): Principal problems of the use of city wastes for crop production and soil conservation. FAO Soils Bull. 27; 221-226.

[27] Vangronsveld, J., Sterckx, J., Van Assche, F. and Clijsters, H. (1995): Rehabilitation studies on an old non-ferrous waste dumping ground: effects of revegetation and metal immobilisation by beringite. J. Geochem. Explor. 52; 221229.

[28] Yang, B., Shu, W.S., Ye, Z.H., Lan, C.Y. and Wong, M.H. (2003): Growth and metal accumulation in vetiver and two Sesbenia species on lead/zinc mine tailings. Chemosphere. 52; 1593-1600.

[29] Ye, Z.H., Whiting, S.N., Lin, Z.Q., Lytle, C.M., Qian, J.H. and Terry, N. (2001): Removal and distribution of iron, manganese, cobalt and nickel with in a Pennsylvania constructed wetland treating coal combustion by-product leachate. Journal of Environmental Quality.30; 1464-1473. 